\title{
Under Western Eyes, or Can Polish Literature just be European Literature?
}

Marta Skwara*

The University of Szczecin

\begin{abstract}
While being a European literature in its own eyes, Polish literature is usually described by outsiders as being one of the Eastern European (East-Central European) or Slavonic literatures. Such umbrella terms not only deprive it of its individual features but also of the Western European and transatlantic connections which have always been important for its development. In this article I scrutinize some of such umbrella terms on the one hand, whereas on the other I present the manners in which Polish authors functioning in the world used to define themselves. Finally, I discuss two examples of recent Polish poetry presented in an English-language poetry anthology in order to ask about a need of discussing European literature under outdated political concepts.
\end{abstract}

Keywords: Comparative Literature, Literary History Concepts, East European Literature, Slavic Literature, Polish Literature

Streszczenie: Będąc we własnych oczach literaturą europejską, literatura polska jest zwykle opisywana z zewnątrz jako należąca do literatur wschodnioeuropejskich (wschodniośrodkowoeuropejskich) lub słowiańskich. Takie pojęcia pozbawiają ją nie tylko indywidualnych cech, ale także powiązań zachodnioeuropejskich i transatlantyckich, które zawsze były ważne dla jej rozwoju. W tym artykule z jednej strony przyglądam się niektórym z takich zbiorczych pojęć, z drugiej zaś przedstawiam sposoby autoprezentacji polskich autorów funkcjonujących w świecie. Na koniec omawiam dwa przykłady najnowszej polskiej poezji zamieszczone w anglojęzycznej antologii poezji, aby zapytać o potrzebę dyskusji o literaturze europejskiej w ramach przestarzałych pojęć politycznych.

Keywords: Literatura porównawcza, Koncepcje historycznoliterackie, Literatura wschodnioeuropejska, Literatura słowiańska, Literatura polska 
By alluding to the title of Joseph Conrad's famous novel, I am going to draw attention to two phenomena connected with international perception of Polish literature: vague concepts applied to it from outside, and external functioning of Polish authors who, like Conrad, entered the English-language world and created their own idiosyncratic voice there.

I shall begin with concepts applied to Polish literature that I find particularly problematic, obscuring its image rather than clarifying it.' The conceptual framework offered by the International Comparative Literature Association (ICLA) in their History of the Literary Cultures of East Central-Europe (2004) is one of them. What most struck me on my first reading of the general introduction to the third volume of the "history" was the strong declaration on the first page:

We describe and analyse common historical mechanisms that operated in the literatures of the region. Thus, the national awakenings that we describe below shared some common frameworks and a common historical mechanism. They followed a common pattern.... (Neubauer 2004: I)

After this statement, the different names of the allegedly simultaneous and consubstantial "national awakenings” are given in Estonian, Albanian, Bulgarian, Czech, Romanian, and Hungarian. There is no name in Polish, and such a name could not have been given, quite simply because there was no "awakening" in the Polish culture of the nineteenth century. In order to think of Polish literature in terms of an "awakening," one has to go back to the Renaissance and the first writers who switched to Polish from Latin. The application of the dictum about a nineteenth century pattern to cultures where it obviously does not fit has various unfortunate consequences. When the History speaks of Polish universities, for instance, Warsaw University, established in 1812, is mentioned first, since that date is compatible with the pattern of the nineteenth century "awakening." Jagiellonian University, established in 1364, is mentioned after that, in an enigmatic remark about the "ancient" Cracow University whose "Polonization" became possible in 1879 within the Austro-Hungarian Empire (idem: 6). Yet this late nineteenth century "Polonization," which would apparently corroborate the desired pattern of "awakenings," was nothing more than a politically motivated revival of the old university's rights and independence. The Cracow (Jagiellonian) University had its real "awakening" in the second half of the eighteenth century, when Polish replaced Latin as the language of instruction.

The wish to integrate all the literary cultures involved within the frame of a common "awakening" also leads to various exclusions. For instance, attention is paid to Samuel Gottlieb Linde as the "compiler of the first great six-volume Polish dictionary" between 1807 and 1814 (idem: 10), even though from a Polish perspective the “first” important philological achievement in Poland was Jan Mączyński's Lexicon 
Latino-Polonorum (Latin-Polish Dictionary) of 1564, which was followed by many others, including the Gramatyka dla szkót narodowych (Grammar for National Schools) published by Onufry Kopczyński in 1778, preparing the ground for Linde's big dictionary. While the ICLA History scrupulously lists many other East Central European nineteenth-century national grammars (idem: IO-II), Kopczyński’s grammar is simply not mentioned. Nor is anything said about Polish in the subchapter "(Re)constructing the Vernacular," for the obvious reason that there was no need to reconstruct Polish in the nineteenth century. Having referred to the supposedly common "language reform" in the East-Central Europe of the nineteenth century, the History then focuses on this in the next subchapter, "Vernacular Literatures and Cultures," beginning with the example of a Hungarian poet who championed poetry in Hungarian "as early as the 1770s" (idem: 13). Then the History discusses the literary situation in Hungary, where Latin was abandoned only in the nineteenth century, as well as other examples of literary reconstructions. As a result, Polish literature, which did not have to rebuild anything, which can boast a poet who championed writing in Polish as early as the mid-sixteenth century (Mikołaj Rej, known as the "Polish Breughel" because of his love of detailed descriptions), disappears from view. Such are the dangers of discussing a large and differentiated literary area in terms of "common mechanisms."

In the History's subchapter on Modernism in East Central Europe, the term "awakening mechanism" is replaced by a distinctly appreciative consideration of "the first serious break with romantic nationalism", said to have been brought about by Polish positivists who "embraced Western ideas on modernization". Yet this is much too simplistic. For one thing, it in effect completely overlooks the role of patriotism in the country which had to fight for its independence for more than a century. For another, the "ideas on modernization" were actually not only of Western origin. And the same subchapter also tells us that the Polish novel was East Central-Europe's strongest representative of Realism, and that "the novels of Orzeszkowa, Świętochowski and, above all, Prus belong to the best achievements of the European realist novel. Prus's Lalka is actually said to go "beyond doctrines"(idem: 49). Imperceptibly, then, the focus shifts from the literature of the region to the literature of Europe.

No matter how much I am flattered by the high opinion of my native literature and the affirmation that it transcends the limits of "the region", I must still contend that Świętochowski was never a great novelist (though a great journalist). The writer of the History could actually have brought in Sienkiewicz at this point. Perhaps it is the work's regional perspective which has made him pour superlatives on a few average novels by Świętochowski, whose harsh criticism of Prus's Lalka long since proved his incomprehension of the modern novel. Anyway, mistakes or misinterpretations are pretty frequent in this part of the History. In the very next sentence we are told that new genres "like Świętochowski's chronicles" were invented by positivist writers, whereas in fact the inventor of those masterly chronicles (Kroniki) was 
Bolestaw Prus. Then again, the "greatness of Polish realism" did not come out of nowhere, but drew on several centuries of national and European literary experience. To try and understand it without that background is very reductive.

In the History the historical narrative is also obscured by being presented in reverse order. The historical "nodes" structuring the history of the literatures of "East-Central Europe" go from 1989 to 1776, which creates a strangely uprooted and mechanically restricted perspective. What the History claims as an important element in the modern manner of writing literary history (idem: 16-18) is really way of wriggling out of the obligation to justify the presentation of the literatures of EastCentral Europe as an "entity" about which one can generalize.

As far as I know, there is no history about the literatures of Western Europe, and it surely is difficult to imagine anyone dreaming up such a project. Would the "history of the literary cultures of Western Europe" seem a natural construction to German, French, Spanish, Dutch, Danish, English, Portuguese, or Italian literary scholars and readers? Two prima facie examples of such a history, Auerbach's Mimesis (1946) and Curtius's Europäische Literatur und lateinisches Mittelalter (1948), were in fact based on completely different premises. Had it not been for the comparatively limited geographical spread of the Polish language, Polish literature might easily have been included in both these seminal works; in Polish literature down the ages, the concept of mimesis and the functioning of ancient topoi are well represented. Or perhaps the real obstacle lay in Polish literature itself, in that it was not as well known as "major" European literatures.

As a specialist in one of the “minor" literatures, I am also struck by the History's paternalistic tone:

Today, one of the important cultural and political questions of East-Central Europe is whether it can overcome its cultural provincialism, whether, after its various awakenings, it can regain in some new form the cultural and literary diversity it once possessed - a diversity of which its past culture still offers some evidence.(idem: 3 )

Instead of commenting in detail on this remark - which sounds like a modern example of the Western Enlightenment narrative of a backward Eastern Europe in constant need of improvement from the outside (Wolff 1994: 26-27) - I will quote the preface published in the first volume of the same History, written by Mario J. Valdés, general editor of the Literary History Project:

We must not forget that this [East-Central Europe] is the literary culture of Mickiewicz, Kafka, Kundera, Lukacs, Wiesel, Ionesco, Miłosz, Mrożek, Szymborska, and Gombrowicz, to name but a few of the many world authors from East-Central Europe. (Valdés 2004: xv) 
Five of the ten authors mentioned here are Polish writers: Adam Mickiewicz, the only one from "the past”, Czesław Miłosz, Sławomir Mrożek, Wisława Szymborska, and Witold Gombrowicz all writing in Polish (and most of them poets). This leaves me with not the slightest fear that I belong to a provincial literary culture which needs to regain some diversity.

As much as I do appreciate the History's many insightful essays on particular literatures or problems, I still find its impressively comprehensive volumes unsatisfactory in their general overviews. Facts which do not fit the favoured pattern are too often distorted or simply omitted. With respect to some epochs and some genres, Polish literature is described, rightly or wrongly, as a "major" literature in the region. In other contexts, however, the chosen general perspective does not even make Polish literature “minor", but simply lets it disappear.

I have far more reservations about describing the literatures of East-Central Europe as a kind of entity than about describing Slavic literatures as an entity. After all, Slavic literatures had common linguistic roots, sometimes shared important ideas such as Romantic "Pan-Slavism”, and experienced periods of close cultural relationship. Even if there are huge historical differences between Polish and Bulgarian literature, or between Czech and Russian literature, in some periods the relationships between them were very close indeed, which was never true of relationships between Albanian and Polish literature or Czech and Estonian literature, all of which find a place, somewhat artificially, under the umbrella of the "East-Central European literatures."

It was Dmitrij Čiževskij, a Ukrainian scholar educated in Tsarist Russia and after 1921 connected with German and American universities, who argued strongly for the importance of Slavic literatures in his Comparative History of Slavic Literatures (1971). One of his obvious aims was to demonstrate the value and European relevance of a literary tradition that was undeservedly neglected in the culture of the West. In Čiževskij’s view, "the Slavic literatures stand largely within the broader community of European intellectual and literary development” (Čiževskij 197ı: 198).

Another of Čiževskij's aims was to oppose the Soviet interpretation of Slavic literatures, which usually described Russian literature as the "major" literature, and which was distorted, neglecting or hiding many important facts. I shall not discuss such travesties in depth, but must at least mention that the Soviet perspective on Slavic literatures has left a bitter aftertaste. Even today, the notion "Slavic literatures" has a somewhat ideological and imperial undertone, which is perhaps one of the reasons for its relative lack of popularity. Partly as a result of this, I believe, the Slavic methodology of comparative literature invented by Dionýzy Ďurišin, with its concept of "interliterary communities", used to function much better in Marxiststructuralist theory than in literary-historical practice. It was applied to Russian and Slovak literatures by Durišin himself, but not to any other Slavic literatures, 
despite the fact that it attracted some attention in certain other parts of the world (Janaszek-Ivaničková 2007: 16-17, 70-81).

Because Čiževskij, in his eager advocacy of all Slavic literatures, did not dwell on differences between the particular literatures in that grouping, so making some of his commentary seem rather self-contradictory, I need to spell out the basic reasons why an account of Slavic literatures as a separate literary area is problematic. Paradoxically, Čiževskij's book can serve as a rich source of knowledge here. Despite its generalizing approach, it still enables us to perceive some important differences between different Slavic literatures.

First of all, Slavonic cultures are underpinned by two different religious traditions: those of the Western Christian Church and of Eastern Orthodox Christianity. This division resulted not only in the adoption of two different alphabets, the Latin and the Cyrillic, a difference which still exists, but also in the development of different approaches to culture and literature. Czechs, Slovaks, Croatians, Slovenians and Poles became part of the western community of the European Christian world, and for a long time they used Latin in their Church and in their writings. Bulgarians, Serbs, and Russians were connected with eastern Christendom and for centuries experienced the profound impact of Byzantine culture. One of the striking examples of the cultural and literary differences between Western and Eastern Slavs was that in the western cultures of the Czechs, Croats and Poles there arose a flourishing Renaissance literature that was closely connected with the Renaissance literature of Italy, France and the Low Countries, whereas in Russia there was no Renaissance at all. Čiževskij himself comments on the pre-Ottoman Bulgarian influence on Russian literature, referred to as the "Russian pre-Renaissance," but only to emphasize that it was not in fact followed by any Renaissance, "at least not in the field of literature" (Čiževskij 197ı: 59).

The foundational West/East differentiation was further deepened by the political history of particular Slavic countries. Roman Catholic Slavs never experienced any long-term domination by Asian and non-Christian powers, whereas Russia was under Mongol rule for about 200 years from the thirteenth century onwards, and Serbs and Bulgarians were under Turkish domination for almost half a millennium. Roman Catholic Slavs, on the other hand, were conquered by Europeans, and the cultural consequences of such political distinctions can hardly be overemphasized. Whereas Czechs almost lost their language under German domination (it had to be artificially rebuilt), the language and literature of Poland positively flourished during the time of German-Russian-Austrian rule - many jewels of Polish literature date from that epoch, with romanticism becoming a touchstone for Polish poetry. In Bulgaria the Turkish invasion confined literary life to monasteries, in which mostly religious literature in Latin was produced, and Bulgarians did not experience a literary revival until the nineteenth century, as did the Serbs as well, and to a different extent 
the Croatians, who were dominated by Germans and Hungarians. Russia was able to liberate itself from its Mongol overlords in the fifteenth century and, after a period of civil wars, slowly began to modernize both its state and its literature. The process gained momentum in the eighteenth century, with Peter I and his secularization of the language, and so did Russian imperialism. From the fifteenth to the eighteenth century, Polish culture was dominant in relation to western Russian culture; wouldbe Byelorussia and Ukraine remained part of the Polish-Lithuanian Res Publica until the Russian partitions of the Res Publica of Two Nations between 1772 and 1795. But from the end of the eighteenth century till the end of the First World War, more than a third of all Poles, and of all the eastern Slavs, were subjects of the Russian czar. After that, and through the second half of the twentieth century (albeit with some differences in political and cultural circumstances from one state to another), all the Slavic countries were dominated by Communist Russia both politically and culturally, with the exception of Tito's Yugoslavia.

If one takes into account these basic historical and cultural differences, how can the concept of Slavic literatures have any real substance? It is true that one can trace important similarities in the origins and development of different Slavic literatures, and down the ages there are also crucial cross-cultural influences, such as: the influence of the earliest Czech writings on Russian literature in the eleventh and twelfth centuries, and then later on Polish literature; the powerful response to Russian realism in most Slavic countries; and the dominance of Socialist Realism from the late 1940s onwards, effected by Soviet communism and the elevation of Russian to the status of an international language, compulsory in all schools within the Soviet sphere of influence. But even so, the various Slavic literatures all have their own complexities, which need to be examined in relation to all the literatures of Europe. Čiževskij, too, knew this, but unfortunately did not mention it until the end of his book:

It must be admitted that research in literary history, and indeed Slavic research as well as West European, has devoted less attention than might be desired to the problems of connections between Slavic East and the European and American West. (idem: 198)

Particularly the literatures that were seen as a tool of national liberation, as was the case with Polish literature, have had more in common with Italian, English, American, French, Dutch, German, Spanish, Swedish, and Danish literature than with other Slavic literatures, which were seldom in a similar situation at the same time. This is very clearly demonstrated in the brief essays on particular literatures brought together in the Reader's Encyclopedia of Eastern European Literature (Pynsent and Kanikova 1993). The author of the essay on Polish literature is Stanisław Barańczak, a Polish scholar, poet, translator, an émigré from People’s Poland, and a professor at 
Harvard University. What he emphasizes is the continuous rich tradition of Polish literature from the early sixteenth century onward, a continuity which is more or less unparalled in other Slavic literatures.

Thus why not drop groupings such as "Slavic literatures" or "East-Central European literatures" altogether and simply talk about these literatures as European literatures? The strongest advocate for understanding Polish literature against a European background is Andrzej Borowski, a modern Polonist and comparatist from Jagiellonian University. He points to the long tradition of European literature sharing the same Graeco-Latin and Biblical roots, displaying much the same set of genres and motifs, using a common literary language (Latin) for a considerable period of time, and exhibiting many cross-cultural contacts over the ages. His conclusion is that all these literatures should not be separated into two artificially created literary areas, but should be compared one with another (Borowski 1999: 7-22).

Polish romantics cannot be understood without their background in classical literature, or without reference to Lithuanian or Ukrainian folk tradition on the one hand, and to French and English literature on the other. An outstanding example of this is Juliusz Słowacki, one of Poland's most imaginative poets and playwrights, who, partly owing to his sophisticated and deeply metaphorical use of Polish, still unfortunately remains just a "Polish" author, as Georg Brandes put it more than a century ago in his famous essay Weltliteratur (2009 [1899]: 63).

Perhaps it is time to overcome such obstacles which, it seems to me, are hardly caused by translation problems alone - after all, even James Joyce's works were translated into Polish - several times! Nor do I believe that modern Polish writers and poets should be seen as standing primarily in the East-Central European tradition and be pressured to live up to some ideal of a once lost diversity. I am not nostalgically waiting for them to regain "in some new form the cultural and literary diversity it [East-Central Europe] once possessed" (Neubauer 2004: 3). My hope would be that they can join the world literary community on equal terms, neither handicapped nor privileged.

Even if Polish literature were to be elevated to the status of a "major" literature both in the Slavic and the East-Central European context - in the latter case becoming artificially and counterproductively free of its “major" Slavic "rival”, Russian literature - I do not think that the future lies in dividing Europe into smaller literary areas, especially when such division is undertaken for mainly political reasons. There used to be a scarcity of information about the literatures of Eastern Europe (and perhaps there still is), but things have certainly changed since the fall of communism in 1989. It would be sad and ironic if the division into Western and Eastern (Central) Europe were re-established, even if it were to occur in a very attractive, almost mythically alluring form, as in a charming essay by Caryl Emerson entitled "Answering for Central and Eastern Europe” and published, ironically enough, at a time when perhaps only 
one Eastern European culture, the Byelorussian, could not freely speak for itself, a fact which tells us much about the real presence of "minor" East-Central European literatures in the world debates on literature. Emerson paints the picture of a "patchwork of small nations". This makes me wonder why Poland, with a population of nearly forty million, belongs in that group. And there are more such questions, as I can signal in square brackets:

All those small peoples who name their streets and public squares, not after generals [?] (for their military victories are few), but after poets ... Central and East Europeans go on growing up with three or four [languages] [?] ... And thus the fertile meta-capacities of the Central European mind: cosmopolitan [?], restless, homeless, a natural translator and hub ... They've had a good look at our Western victories as well as at our patterns of protest and are indifferently impressed [?]. We could begin learning from them. (Emerson 2006: 203-210)

No matter how alluring and flattering the picture may be - even a bit mystical, with its evocation of some hidden "potentiality" in East Central Europe (idem: 209-210) - it is not likely to improve the handicapped position of these literatures. Perhaps we (and I use the pronoun "we" with the "taste of special irony" Emerson ascribes to Central and East Europeans) are more like the students whom Emerson describes, expecting that "history or hearsay should be made real"? "We" - I dare to paraphrase Emerson - do "have to be made real." But that is not going to happen through transforming the area once "frozen into the fake homogeneity of the Warsaw Pact" (idem: 204) into the beautifully frozen heterogeneity of Central and East Europe, a region expected to deliver wonders such as a mythical redemption of the past. It will happen when "we" start to be perceived as old, yet perhaps hitherto oddly absent citizens of the literary republic of Europe.

Tellingly, Polish poets functioning in the world have never developed an Eastern European perspective, their "native realm”, to use the title of Miłosz's autobiographical essays, was simple Europe. To them, as to other members of literary cultures of "Eastearn Europe" with its shifting borders, "Eastern European literature” was a purely political concept. As a Hungarian poet and academic George Gömöri put it in 1967:

It is debatable whether there has ever been such a thing as "East European Literature". Perhaps one should regard it as a vague definition at best, something like the literature of "the Soviet people". There is still no such thing as the Soviet people ... . Whatever uses the term "East European" may have, it gained wide currency only after the Second World War, when Poland, Czechoslovakia and Hungary, countries which for a long time thought about themselves as being "central" to Europe, forming a "bridge between East and West" or an outpost against "the Eastern hordes", suddenly found themselves firmly implanted in Eastern Europe. (Gömöri 1967: 9) 
Thus "Central” was perceived by Gömöri not as a supplement of "East" as it functions in the concept of "literary cultures of East Central-Europe" but as its contradistinction. One belongs to "Central Europe" or to "Eastern Europe”, with poignant mental consequences. The political dimension of "East European literature" was brought about to paradoxes by Emery George. Not only did he include GDR authors to his anthology of "East European Poetry" (for some reason East German authors have been rarely discussed under the concept of "East-Central-European literature") but also made a significant remark: "if Goethe and Schiller were alive today they would be East German writers” (Emery 1993: 153). To Adam Zagajewski, a Polish poet and literature professor at the University of Chicago, the East-West division of Europe was not only political but also inferior to the real cultural difference:

you must remind yourself that Europe comprises both the Latin South and the Barbaric North and that this division predates Yalta and other such treacherous treaties, and the North is also divided, and I too am divided. (Zagajewski 2002: I86)

However, it does not mean that Zagajewski simply wished to re-establish preEnlightenment cultural imaginary from before the times when the cultural East was invented by the Enlightenment minds and which - as Wolff presented it clearly - prevails up to these days in the common knowledge on Eastern Europe. Instead he, as many other "East European" poets and writers, tried to express the tension of those who struggle with their cultural affiliation to the West and their geographical belonging to the East. On defying Zbigniew Herbert's unique poetic voice, Barańczak described this tension as: "a fundamental contradiction between his attachment to the values of Western cultural "heritage" and his awareness of the Eastern European's irreversible state of “disinheritance”" (Barańczak 1987: I).

Quite characteristically, Eastern European literature did not exist for the most prominent nineteenth century example of Polish poets lecturing on literature in the West - Adam Mickiewicz, a professor at the Collège de France in Paris. During his Paris lectures delivered in French in 1841-1844, Mickiewicz attempted to present Slavonic literary world to the Western audience, both in its historical development and through its similarities and differences. His main point was to contradict more spiritual culture of the Slaves, as he saw it, to more material culture of the West. His deepest insight was into Polish literature (unfortunately, he excluded himself almost completely due to his modesty as a lecturer) but he also made various interesting comparisons both among Slavonic authors and literatures themselves, and their connections with other European literatures. The poet in the role of a professor also introduced new philosophical perspectives, most originally Ralph Waldo Emerson's ideas. Certainly, his aim was not to describe Slavonic literature but to connect it, even if by contrast sometimes, with the whole European and transatlantic writing and thinking. 
Miłosz, while beginning his career at the American university (Berkeley, California), partly out of didactic needs conceived a handbook on Polish literature in English (The History of Polish Literature, 1969). He paid much attention to historical and political contexts, idiosyncrasies and worldliness of Polish poets and writers but also elaborated issues that interested him personally, such as a theological culture. Eastern European category was not a point of reference to him until the post-war times, and even then he preferred to use terms such as "Soviet models" which were imposed on Polish literature in the first decade after the WWII. Already what happened after 1956 was to Miłosz a true revival:

A multitude of writers came to the fore whose debuts had been delayed because of their refusal to bow to ideological exigencies during the preceding period... Polish poetry, now freely profiting from experiments of two prewar decades and from its precursor, Cyprian Norwid, was one of the most vigorous in Europe through its intellectual and existential grasp of tragic political choices. (Miłosz 1969: 458)

Later not only Miłosz co-translated and edited an anthology of Polish poetry in English as well as volumes of particular Polish poets whom he appreciated most (Zbigniew Hebert, Aleksander Wat, Anna Świerszczyńska (Swir)) but also included Polish poets into his international anthology of poetry (A Book of Luminous Things, 1996). His wish was to unite poets of the world who created "poetry loyal toward reality and attempting to describe it as concisely as possible" (Miłosz 1996: xv). Nowhere in the anthology the factor of Miłosz's choices was an East/West distinction (and East would have to mean something much different regarding a considerable amount of classical Chinese poems included in the anthology) but a unique poetic ability to reach the state of epiphany, an illumination through poetic description of objects or scenes:

Epiphany thus interrupts the everyday flow of time and enters as one privileged moment when we intuitively grasp a deeper, more essential reality hidden in things or persons. A poem-epiphany tells us about one moment-event and this imposes a certain form. (Miłosz 1996: 3)

Particularly interesting persona in presenting Polish literature in the Englishlanguage world was Jerzy Pietrkiewicz (Peterkiewicz), a poet and writer himself, and a professor of the University of London. In his main academic achievement Polish Literature in its European Context (1962) he attempted to investigate existing literary connections and draw interesting parallels between Polish and European literature. The need to place Polish poets against the most relevant European background, which to Pietrkiewicz hardly ever was Eastern European context, is clearly seen also 
in his anthology Five Centuries of Polish Poetry 1450-1950 (1960). When describing the most original Polish romantic Cyprian Norwid, Pietrkiewicz placed him close to G. M. Hopkins, Laforgue or Ezra Pound, and when discussing Polish idyll, known as a national specialty under the name sielanka, he referred to the pastoral convention of Theocritus and Virgil in the first place.

There were other Polish poets, active as translators, essayist and literature teachers in the $2 \mathrm{O}^{\text {th }}$ century English-speaking world: Barańczak and Zagajewski quoted above, Bogdan Czaykowski and Andrzej Busza (both from the University of British Columbia) or Adam Czerniawski connected with many British schools. Being poets, they all paid particular attention to Polish poetry and its function both in its native and world context. Not surprisingly, East Europeanness appeared in their reflections mostly as a political term, applied to the communistic period. Especially Barańczak, who immigrated to the US in 1981 that is in the last convulsive and tragic period of the communistic Poland, played with the label both in his poems and in his collection of essays on Polish literature and culture (Breathing under Water and Other East European Essays, 1992). For instance, an Eastern-European as a subject of Barańczak's poems written in the US could not come to terms with the conventional stand-up party small talks. They not only seemed meaningless to him but also inhuman (tellingly, entitled "Small talk” the Barańczak's poem was originally written in Polish). As a subject of his essays an Eastern-European, allusively abbreviated as an E.E., gave an account of his historical and cultural experience as follows:

As an Eastern European born in a totalitarian country, I was well trained for two things, and by two very different coaches. The Immovable History of my nation taught me that in my part of the world nothing ever changes, and that it's safer not to harbor any hope. The Recalcitrant Literature of my nation taught me that having no hope does not preclude demanding change... (Barańczak 1992: 6)

Since that self-definition was noted when he "did not know that he lived at the end of a historic era”, Barańczak recognized his own words as "outdated" already in 1992.

From outside, however, modern Polish poetry, even the most recent young poets, have long been presented as belonging to a group of East-European literary culture, marked by a heavy historical experience. A good example of such a long-lasting attitude can be a quote from Vaclav Havel (a writer himself, and the first president of the post-communist Czechoslovakia) placed in A Fine Line, a volume containing "new poetry from Eastern \& Central Europe”:

The anthology of poetry you are holding in your hands represents a window into the minds and souls of nations who have in recent history been denied the freedom to make decisions about themselves. Readers who have grown up in liberal conditions are thus 
given the opportunity to glimpse the inner worlds of those who were not so lucky, and to do so through poetry which - if honest - frees us all together from the bonds of ephemeral life. Vaclav Havel. (Boase-Beier et alii 2004: II)

Fortunately, a note from the back cover of the same book makes the picture much more varied. Neal Ascherson, a Scottish journalist and writer, points out to young age of the authors, whose historical experience is much different than that of their grandparents and parents (about whom Havel seemed to speak):

Their poise and their self-possession are starting; they seldom lament and have no interest in preaching. The encounter with the Western abundance gives them fresh imaginary, but also grounds for amusement and irony. From their part of Europe, they bring a special joy in the natural and physical world, and also glittering metaphysical brilliance. This is a poetry of wit and complexity, never raw but always glowing with human feelings. (Boase-Beier et alii 2004, back cover).

"Wit and complexity" seem particularly fitting concepts when Agnieszka Kuciak, the first of two Polish poets presented in the anthology, is concerned. Born in 1970 (which is more or less my generation) the academic and translator debuted as a poet in 2001 with an outstanding poetry collection Retardacja (Retardation), and soon published her second book of poetry Dalekie kraje. Antologia poetów nieistniejq̨cych (Distant Lands. An Anthology of Poets who Don't Exist, 2005). It would be difficult to match her with any East-European pattern, perhaps indeed only her ironic and parodistic talents, compared in the anthology's short bio-note to Szymborska's skills, would fit in. Yet Kuciak's irony goes much farther than Szymborska's, and embraces both Polish and world poets. One of her few poems presented in the anthology - "Wagary w święto," ("Playing Truant on Sunday" in Antonia Lloyd-Jones's translation, or more literary: "Truancy on a Holy Day") - depicts kids playing hooky from God "who can be possessed by devils from time to time, as every kid knows." Thus children es cape to the lake, but still keep bowing down when swimming:

Pozornie lekko musowata w wodzie

- jak rozpuszczona oranżada - nasza

Nieletnia dusza. Rozpuszczone dzieci!

Zasłużyliśmy na porządne lanie:

Apokalipsę, gorejący krzew.

Our under-age souls seemed to fizz

In the water gently - like dissoluble

orangeade. What dissolute children we were! 
We deserved a good, sound thrashing:

And apocalypse, or a burning bush. (Antonia Lloyd-Jones)

This example of how Polish poetry can sound nowadays ${ }^{2}$ is also a good example of what the world reader might miss. Kuciak's poem was republished in the anthology without the ironic entry on the author of the poem accompanying the original Polish edition. According to the entry, the author was a certain "N. Miłosz" described in the dictionary attached to Kuciak's second poetic book as "a poet of amiable faith, known as "<the bishop of poetry>" who "has lyrically consecrated countless lakes and landscapes," and who believes "in the sacrament of poetry readings, the poem as penance, and the grace that comes from literary prizes. He writes, however, only about God" (Kuciak 2013: 17). The poet's family name cannot be alien even to foreign readers of Polish poetry, although the ironic description of his artistic emploi may be fully readable only to Poles familiar with poetic discussions in which a strong position of Miłosz (Cz. Miłosz!) has been gradually undermined over last decades. On the other hand, the reader also finds in Kucińska's second poetic book a poetess named Sylwia, depicted as "a poet of resentments", "shallow as a pond of tears", who authors a self-referential poem entitled "Depressia," (an obvious allusion to Sylvia Plath). Another poet invented by Kucińska and simply called Nobody, opens the volume with a poem on rain who is "a Zen master" and keeps raining "like on that big night,/ when the street vendor tried to sell us roses/ but we didn't want any roses, / we wanted life itself" (Kovacek). In the figure of Nobody Kucińska's irony and wit are driven to the extremes since Nobody is the most obvious alter ego of the poet herself, famous for believing that "she doesn't exist, has never existed, and will not exist in the future, a fact that has driven countless literary critics to distraction" (Kuciak 2013: 17).

The second representative of "new" Polish poetry in the anthology, Edward Pasewicz (born in 1971), is presented as the author of poetry collection "entitled Lower Wilda, which appeared in 2002 to critical acclaim". The international reader is also in formed that the collection "introduces openly gay themes into young poetry in Polish literature" (Boase-Beier et alii 2004: 104). Grzegorz Musiat, a poet of the former generation (born in 1952) who in fact was the introducer of openly gay themes into "new" Polish poetry (and a devoted translator of Allen Ginsberg) must have felt offended. Particularly since his gay poetry figured prominently in English language books of poetry, not least in the big anthologies such as Walter Cummins's Shifting Borders. East European Poetries of the Eighties (1989), or Donald Pirie's Young Poets of a New Poland (1993). Paradoxically enough, not the famous "open gay poetry" is presented in A Fine Line but metaphoric, reflective and ambiguous Pasewicz's poems, which were made a bit more equivocal by translator's choices. In the below quoted poem Polish pragnienie (longing, yearning) is changed into much more sensual desire (which would be pożądanie in Polish), and a metaphoric verb przyłapać denoting "catching 
somebody in an act of doing something" (catch out) is transformed into the physical act of catching. Thus the English speaker of Pasewicz's poem seen at peeling off potatoes becomes more an object of "a seizure" than a receiver of a tender gesture offered in a hostile world.

Pierwszy plan - ciemne ujęcie

Pragnienie to tylko karuzela, kurczak

To tajemnica ciała. I przyłapujesz mnie czule

Z nożykiem zawieszonym nad wiadrem, Czasami potrafię płakać. Monstra chodzą

Obok naszego domu i zaciskają szczęki.

Plan A - Dark Seizure

Desire is merely a merry-go-round, a chicken

The secret of the body. And you catch me tenderly,

With my knife dangling over the pail.

At times I manage to cry. Monsters walk

Alongside the house, clenching their jaws. ${ }^{3}$ (W. Martin)

Also a thriller-like effect disappeared from the translation since the title "seizure" replaced the original ujęcie (shot) corresponding with another original movie term: pierwszy plan (the foreground).

The need to present "the first" voices from still unknown and sometimes almost legendary parts of Europe seems to neglect the fact that we talk about poetry of about eight ages, where even the newest and the freshest voices have their roots and their intertextual connections, both with Polish and with world poets (and artists, and philosophers). Nothing comes out of nowhere, and not everything is limited to East European charms or curses. Neither separating "new voices" from their significant literary heritage nor ascribing them to "East(Central) Europe" literary culture is particularly helpful in understanding what European literature once was and what it is now. 


\section{Notes}

\footnotetext{
* Marta Skwara - a professor of Polish and Comparative Literature, the head of the Comparative and Translation Unit at the Literature and New Media Department at the University of Szczecin, Poland; the editor-in-chief of the Rocznik Komparatystyczny/Comparative Yearbook published in Szczecin in co-operation with the Universities of Warsaw, Cracow, Brussels (UIB), Greifswald, Barcelona, Zagreb; a member of the executive board of the Polish Comparative Literature Association; a founder member of the Transatlantic Walt Whitman Association. Interests: Polish and comparative literature, reception studies, translation studies, European and transatlantic romanticism, modernism and postmodernism.
}

'I wrote more about it in Skwara (2015).

${ }^{2}$ Original free lines are curbed in almost regular II-sylabble line pattern, with classical devices like enjambement and alliterations still playing important roles. While the alliteration was kept in translation (dissoluble/dissolute), the enjambement plays a much weaker role - originally the "under-age soul”, the subject of the first sentences, was placed only at the beginning of the third line.

${ }^{3}$ These clinching is "womanly" and their walk "dancing", as we read in the next two lines concluding the poem.

\section{Works Cited}

Auerbach, Edward (1969 [1952]), "Philology and Weltliteratur," Trans. Edward and Marie Said, The Centennial Review no 13, 1-17.

Barańczak, Stanisław (1992), Breathing under Water and Other East European Essays, Cambridge, Mass., London, Harvard Univ. Press.

Boase-Beier, Jean/ Büchler, Alexandra/ Sampson, Fiona (eds) (2004), A Fine Line. New Poetry from Eastern \& Central Europe, Edited by With a Preface by Václav Havel, with an Introduction by Fiona Sampson, Arc Publication.

Borowski, Andrzej (1999), Powrót Europy, Kraków, Księgarnia Akademicka, Wydawnictwo naukowe.

Brandes, Georg (2009 [1899]), "Weltliteratur," Trans. Haun Saussy, in The Princeton Sourcebook in Comparative Literature. From the European Enlightenment to the Global Present, ed. by David Damrosch / Natalie Melas / Mbongiseni Buthelezi, Princeton and Oxford, Princeton University Press. 
Čiževskij, Dmitrij (197I), Comparative History of Slavic Literatures, Trans. Richard N. Porter, ed. by Martin P. Rice, Baltimore, Vanderbilt University Press.

George, Emery (1993), Contemporary East European Poetry. An Anthology, Expanded edition, edited by Emery George, New York, Oxford University Press.

Emerson, Caryl (2006), “Answering for Central and Eastern Europe”, in Comparative Literature in an Age of Globalization, ed. by Haun Saussy, Baltimore, Johns Hopkins University Press, 203-2II.

Gömöri, George (1967), "Literature deprophetized. New trends in East European Literature”, in “Tri-Quarterly" no 9, 9-20.

Janaszek-Ivaničková, Halina (ed.) (2007), The Horizons of Contemporary Slavic Comparative Literature, Warsaw, Dom Wydawniczy “Elipsa”.

Kuciak, Agnieszka (2013), Distant Lands. An Anthology of Poets Who Don't Exist, Trans. Karen Kovacik, Buffalo, New York, White Pine Press.

Milosz [Miłosz], Czeslaw [Czesław] (1996), A Book of Luminous Things. An International Anthology of Poetry. Edited and with an introduction by C. Milosz, San DiegoNew York-London, A Harvest Book, Harcourt Brace \& Co.

-- (1969), The History of Polish Literature, London, The Macmillan Company, CollierMacmillan LTD.

Neubauer, John (2004), “General Introduction”, in History of the Literary Cultures of East Central-Europe: Junctures and Disjunctures in the 19th and 20th Centuries, ed. by Marcel Cornis-Pope/ John Neubauer, vol. 3, I-38, Amsterdam, John Benjamins. DOI: I0.1075/chlel.xix.05cor

Peterkiewicz [Pietrkiewicz], Jerzy/ Singer, Burns (1960), Five Centuries of Polish Poetry 1450-1970: Anthology with Introduction and Notes, London, Secker \& Warburg.

Pynsent, Robert B/ S. I. Kanikova (eds) (1993), Reader's Encyclopedia of Eastern European Literature, New York, HarperCollins.

Skwara, Marta (2015), ”Between 'Minor' and 'Major': The Case of Polish Literature”, in Major versus Minor? Languages and Literatures in a Globalized World, Ed. Theo D’Haen / Iannis Goerlandt / Roger D. Sell, Amsterdam/Philadelphia, John Benjamins Publishing Company, 221-23ı.

Valdés, Mario J. (2004), "Preface by the General Editor of the Literary History Project”, in History of the Literary Cultures of East Central-Europe: Junctures and Disjunctures in the 19th and $2 \mathrm{O}^{\text {th }}$ Centuries, ed. by Marcel Cornis-Pope / John Neubauer, vol. I, xiii-xvi, Amsterdam, John Benjamins. DOI: I0.I075/chlel.xix.05cor Wolff, Larry (1994), Inventing Eastern Europe: The Map of Civilization on the Mind of the Enlightenment, Stanford, Stanford University Press.

Zagajewski, Adam (2002), Another Beauty, Translated from the Polish by Clare Cavanagh, Forward by Susan Sontag, Athens, The University of Georgia Press. 